\title{
CREATING LOW-COST ANIMATION VIDEO USING ONLINE PLATFORM: A LEARNING MEDIA USER REVIEW
}

\author{
Noviarina Kurniawati ${ }^{1 *}$ \\ ${ }^{1}$ Department of Medical Education and Bioethics, Faculty of Medicine, Public Health and Nursing, Universitas Gadjah Mada, \\ Yogyakarta - INDONESIA
}

Submitted: 17 Jan 2020; Final Revision from Author: 24 Mar 2020; Accepted: 25 Mar 2020

\begin{abstract}
Background: A shift in modern learner learning preference and expansive growth of computer capacities leads to a more widely use of multimedia instructions, including animation videos. Creating animation instructions can be time and resource-consuming. A means of low-cost animation video making platform is favorable. This article aims to review an example of online platform for animation video making.

Learning Media Review: Powtoon ${ }^{\circledR}$ is an online video making and editing platform for producing 2D animation videos. It provides animation attributes, i.e. icons, characters, text, background pictures, etc., and editing technology. The features can be accessed in several bundling and pricing alternatives depends on users need. The article also describes some points in terms of advantages and disadvantages of this online platform. Animation in education can be used for gaining learners' attention; demonstration of a process or procedures; and supporting explanation for conceptual understanding. Brief discussions about educational theories related to animation video development and use are included.

Conclusion: Alternatives of online platforms are available and can be used to develop low-cost educational animation video. Teachers as designer should develop a meaningful concept and storyline guided by the application of sound educational theories during the development and in class implementation.
\end{abstract}

Keywords: animation video, low-cost learning resource, technology enhanced learning, computer assisted learning

\section{ABSTRAK}

Latar belakang: Pergeseran kecenderungan belajar para pembelajar modern dan pertumbuhan kapasitas komputer yang pesat mendorong meluasnya penggunaan bahan ajar multimedia, termasuk video animasi. Pembuatan video animasi untuk pembelajaran kadangkala membutuhkan waktu yang cukup lama dan sumber daya yang cukup besar. Dibutuhkan adanya platform atau program yang dapat membantu pembuatan video animasi tanpa menghabiskan terlalu banyak waktu dan sumber daya. Tulisan ini bertujuan untuk menelaah sebuah platform pembuatan video animasi yang tersedia secara daring.

Learning Media Review: Powtoon ${ }^{\circledR}$ adalah sebuah platform pembuatan dan penyuntingan video animasi 2D (2 dimensi) yang tersedia secara daring. Platform ini menyediakan komponen-komponen pembuatan animasi, misalnya: ikon, karakter, huruf, gambar latar, dsb. Serta teknologi untuk melakukan penyuntingan video. Fitur-fitur yang tersedia dapat diakses dalam berbagai macam paket dan harga sesuai kebutuhan pengguna. Artikel ini juga menjabarkan beberapa poin terkait kelebihan dan kekurangan platform daring ini. Animasi dalam pendidikan dapat digunakan

*corresponding author, contact: noviarina@ugm.ac.id 
sebagai pencantum/penarik perhatian pembelajar, medium peragaan suatu proses atau prosedur, dan penjelasan untuk mendukung pemahaman suatu konsep. Diskusi singkat mengenai teori-teori pembelajaran yang terkait dengan pembuatan dan penggunaan video animasi juga disampaikan dalam artikel ini.

Kesimpulan: Berbagai pilihan platform daring untuk pembuatan video animasi teleah tersedia. Berbagai platform tersebut dapat digunakan untuk membuat video animasi berbiaya rendah. Dosen sebagai desainer pendidikan harus menyusun sebuah konsep yang bermakna dan storyline yang berlandaskan pada teori pendidikan yang sesuai dalam proses pembuatan dan penggunaannya dalam pendidikan

Kata kunci: video animasi, bahan ajar murah, pembelajaran berbasis teknologi, pembelajaran berbasis komputer

\section{PRACTICE POINTS}

- Available online for academia to create animation video with minimum technical requirement or graphic design background.

- Supporting low-cost multimedia learning resource production.

- Instructional design and use of the product for learning should be based on sound educational theory.

\section{INTRODUCTION}

Digital environment is a familiar concept for modern learner both in their educational setting and outside. Modern learners are basically of Millennials, born between year 1980 and 1999, and Generation Z, born in year 2000 and 2015. Both generations are fluent users who "live" the digital environment and get exposed in a very early age. ${ }^{1}$ Heavily multitasking in digital world is common and natural for these generations. These users demand for constant availability of information sources and are more likely to use internet as their primary source for information searching. ${ }^{2}$

In accordance, the expansive growth of computer capacities leads to a more widely use of multimedia instructions, including animation videos. ${ }^{1,3}$ Creating animation instructions, however, can be time and resource-consuming, especially when third party production house involved. The availability of free or low-cost animation production that can be used independently by teachers are favorable. This article aims to review an example of free online animation maker platform to provide insight about the potentials and challenges of such technology.

Nowadays, there are choices of technology ready for animation making. Animation can be developed using Flash or HTML5. These programs requires computational coding skills. ${ }^{4}$ The more familiar technology for the teacher includes presentationmaking programs, e.g. Microsoft Power Point, Keynotes, Adobe After Effect, etc. These programs are generally provided by educational institutions, hence no actual cost burden for the teachers. However, these programs need some degree of technical skills and knowledge for creating animated presentations. ${ }^{5,6}$

Another alternative is online animation video maker platforms. There are several options regarding brands and services, e.g. Powtoon $\AA$, Moovly $\AA$, Vyond ${ }^{\circledR}$ (formerly known as Go Animate), Videoscribe $\AA$. In general, these platforms offer better user-friendliness than the aforementioned programs. Some differences among these platforms include the intended audience, pricing, and support service. For instance, features in Moovly® supports general non-professional audience; Vyond $\circledast$ and Videoscribe ${ }^{\circledR}$ target organizational and company of all size; and Powtoon $\AA$ has separate features for educational institution of any level. Powtoon $\AA$ and Moovly ${ }^{\circledR}$ provide both free and paid versions, while Vyond $\AA$ and Videoscribe ${ }^{\circledR}$ are only available in paid version with free trial in limited time. All platforms mentioned are available in online-only service, except 
for Videoscribe ${ }^{\circledR}$ that allows purchase of license for offline use. Based on these features, this article will focus on Powtoon $\AA$ for its better suitability in providing a low-cost learning media development.

\section{LEARNING MEDIA DESCRIPTION}

Powtoon $\AA$ is an online video making and editing platform for producing 2D animation videos. It can be accessed via https://www.powtoon.com/ using any browser in a computer that allows for graphic program to run. This United States based platform was launched in 2012 by four co-founders and claimed to, until December 2019, has been accessed by 10.000 users over the world with approximately 20.000 new users enrolled every day. ${ }^{7}$

Powtoon $\AA$ enables the users to create their own animation videos by providing animation attributes, i.e. icons, characters, text, background pictures, etc., and the technology needed to animate those components. It also provides various effects and video editing tools to round up the whole video production process. Users can choose the icons and place it on the selected background to create a scene and easily add the animation effect by clicking on the buttons (see Figure 1 and 2).

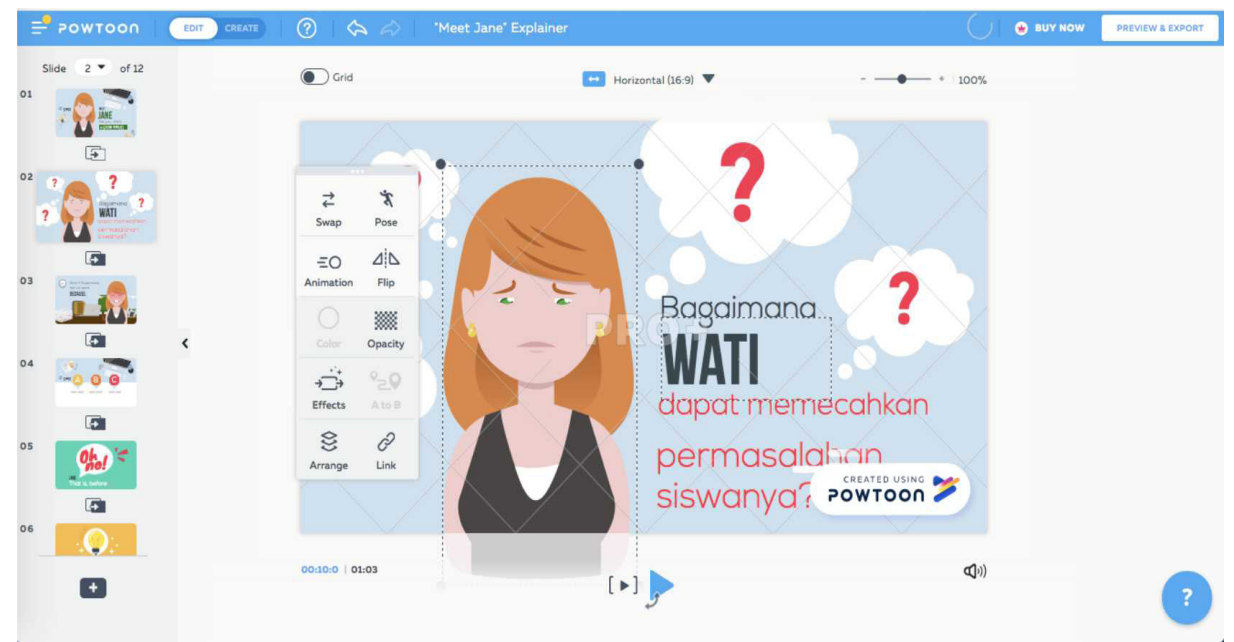

Figure 1. Creating a scene and text in Powtoon $\AA$

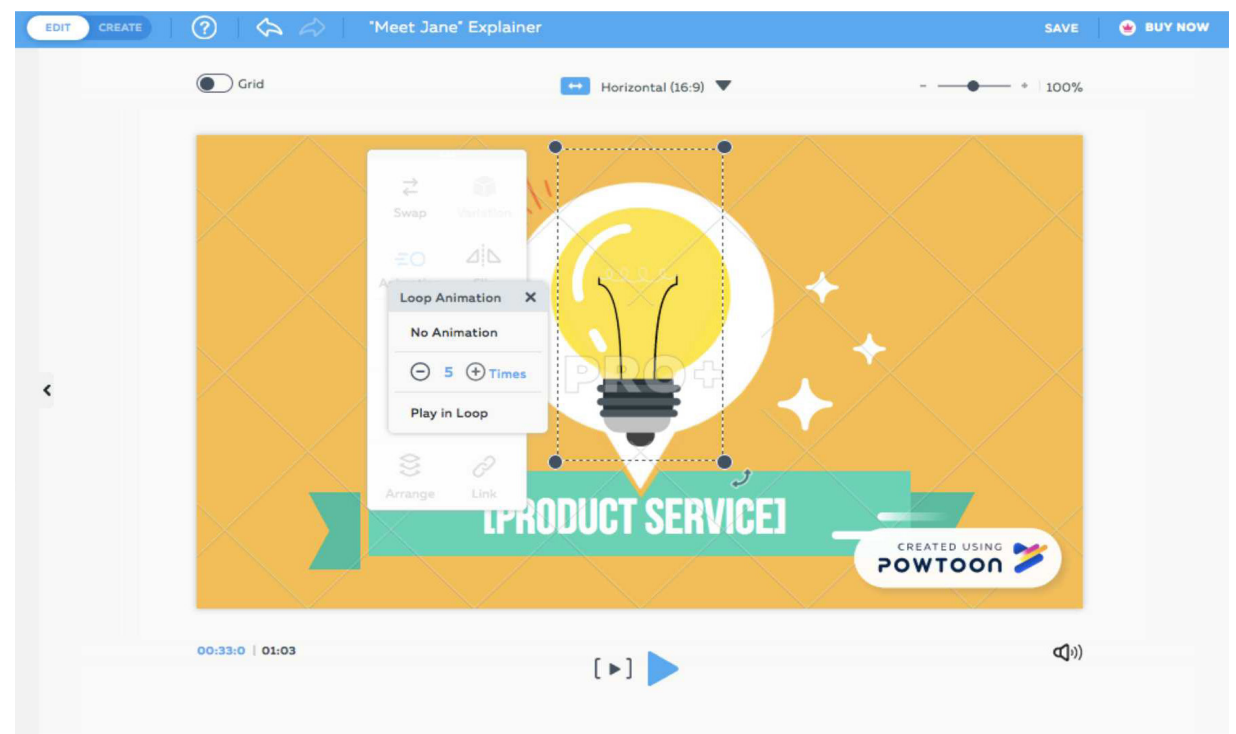

Figure 2. Adding animation and effects in Powtoon $®$ 
Users can also opt out adding and creating animation using the provided characters. Instead, they can upload their own PowerPoint ${ }^{\circledR}$ presentation and convert it into videos using royalty-free footage provided in the platform.

All these features are offered in several different bundles with different pricing. By the time this review is written, Powtoon ${ }^{\circledR}$ has four subscription schemes starting from 0 USD (free) for the regular basic subscription, up to customized education license, premium individual subscription, and business package. $^{?}$

To access the features, users have to create an account in Powtoon ${ }^{\circledR}$ website or login using one of user's existing social media profile. As many other websites, users can set their username and password after they get logged in. The free regular features can be accessed right after. The most significant difference between the regular and premium subscription is the personalized technical support they give for each different subscription. Another easily recognized difference is the Powtoon ${ }^{\circledR} \log$ omission or logo customization for the end product.

Not only technology features are offered by Powtoon ${ }^{\circledR}$, but also a Social Network System (SNS) that enables users to upload their videos and share them to other users in the network. This feature allows teachers who wants to utilize animation videos for teaching to browse and use (with permission) videos uploaded by other users as well. If user does not wish to publish their videos online, they can also choose to save it to their device instead of uploading it to the SNS. Complete features and contact information can be browsed in the official Powtoon ${ }^{\circledR}$ website.

\section{DISCUSSION}

A study by Animation in education can be used for gaining learners' attention; demonstration of a process or procedures; and supporting explanation for conceptual understanding. 3 The latter is the most frequently used for trainings and lectures. They are often called as expository animation or explanatory animation in other names.

Creating animation video should be preceded by developing a storyline. Storyline contains the outline, details of each scene and sequences of frames that guides the video production. More importantly, storyline helps the designer to apply the appropriate educational theory during the animation development process. This principle has led to various use of Powtoon $\AA^{\circledR}$ in educational area. Powtoon ${ }^{\circledR}$ is used commonly for delivering content, but there has been a report about how teacher asked the students to create a public health content using Powtoo $\AA$ to help students apply the theory. 8 Another document shows that Powtoon was used not only for its ability to deliver content, but also to emphasize the importance of the multimedia development process itself. ${ }^{9}$

Normative educational theory provides overview on the characteristics of the learner to be targeted and, therefore, informs the animation designer about the objectives of the design(10). Other educational theory to be considered in the animation making are the theories that provide guidance on how to develop helpful learning resources, such as cognitive load theory and multimedia theory.10,11 Online video making platform provides the technology to create the animation video, however, the responsibility to develop a working framework in the form of a storyline still lies on the teachers as education designer. Some online platforms, including Powtoon ${ }^{\circledR}$, offer services for storyline development for additional cost or premium bundling. This service can be useful only if the teachers already have a robust concept on the subject they are going to turn into animation.

In regard to the nature of SNS, using an existing learning material created by other people has its own advantages and disadvantages. On one hand, it eases the teacher, saves time and energy, and encourage collaboration. In the other hand, the available videos might not entirely suit the subject being taught,12 not to mention the copyright issues that have to be considered carefully.

In summary, there are potentials and challenges that comes from the use of online animation video maker platform as listed in the table below. 
Table 1. Potentials and challenges of Powtoon $\llbracket$ for animation video making

\section{Potentials}

Challenges

Ease of use and user friendliness interface. Technology The need of internet to access and work. Other provided in Powtoon ${ }^{\circledR}$ is simple enough and requires technological requirements might include certain only minimum design and computer skills. computer specifications and operating system,

Low-cost. They provide basic regular features for free. Users need to be aware of the copyright issues, digThis allows beginner users, be it teachers or students, ital scholarship ethics, and private data security. to explore and improvise without financial burden. They should respect others right and privacy and be able to take measurement to protect their own as well so as not to be involved in digital infringement.

Collaborative community. The SNS and communi- The end product resulted from free regular featy support forum, users are encouraged to share and collaborate. This feature could also be turned into peer-feedback activity.

tures in Powtoon ${ }^{\circledR}$ contains logo and short advertisement at the end. To omit or customize this part, users need to upgrade the service into premium subscription.

\section{CONCLUSION}

Online animation making platform, e.g. Powtoon ${ }^{\circledR}$, can be used to develop low-cost educational animation video. Rather than technical aspects, teachers need to put more emphasize in developing meaningful content, a logical storyline, and applying educational theory-based instructions in order to produce quality educational animations using this online platform. Apart from the technology choice, application of appropriate educational theory is an important step for the development process and utilization of animation video in medical and health professions education.

\section{RECOMMENDATIONS}

This article exposes only an example among vast arrays of available video production platforms. Using this article as the first guide, readers are advised to explore more deliberately other platforms as well until they arrive at the most suitable platform to their particular needs and conditions. Future study could be done to compare the mentioned platform in this article with other platform in various terms such as development process, usability, user acceptance, or product quality. Possibilities of studies involving educational parameters and impact are also open and important ones.

\section{LIST OF ABBREVIATIONS}

SNS: Social Network System. a dedicated website or other application which enables users to communicate with each other by posting information, comments, messages, images, etc.

HTML5: Hypertext Markup Language generation 5. A standardized system for tagging text files to achieve font, colour, graphic, and hyperlink effects on World Wide Web pages.

\section{COMPETING INTERESTS}

The author certify that they have no affiliations or involvement in any organization or entity with any financial interest or non-financial interest in the subject matter or materials discussed in this manuscript.

\section{AUTHORS' CONTRIBUTION}

Noviarina Kurniawati does the literature review, product testing and manuscript compositions for the article in hand.

\section{REFERENCES}

1. Ruiz JG, Cook D a, Levinson AJ. Computer animations in medical education: a critical literature review. Med Educ. 2009 Sep;43(9): 838-46. 
2. Kirkwood A. Getting it from the Web: Why and how online resources are used by independent undergraduate learners. J Comput Assist Learn. 2008;24(5):372-82.

3. Berney S, Bétrancourt M. Does animation enhance learning? A meta-analysis. Comput Educ. 2016 Oct;101:150-67.

4. Laaser W, Toloza EA. The Changing Role of the Educational Video in Higher Distance Education. Int Rev Res Open Distrib Learn. 2017;18(2):264-76.

5. Bellei M, Welch P, Pryor S, Ketheesan N. A Cost-Effective Approach to Producing Animated Infographics for Immunology Teaching-appendix. J Microbiol Biol Educ. 2016 Dec;17(3):477-9.

6. Cant RP, Cooper SJ. Simulation in the Internet age: The place of Web-based simulation in nursing education: An integrative review. Nurse Educ Today. 2014;34(12):1435-42.

7. Powtoon. About Us | Powtoon [Internet]. 2019 [cited 2020 Jan 2]. Available from: https://www. powtoon.com/aboutus/
8. Wallace H, VanderMolen J. Teaching Health Education Through the Development of Student Centered Video Assignment. Front Public Heal. 2019; 7 (November): 1-7.

9. Günaydin S, Karamete A. Material development to raise awareness of using smart boards: An example design and development research. Eur J Contemp Educ. 2016;15(1):114-22.

10. Sandars J, Patel RS, Goh PS, Kokatailo PK, Lafferty N. The importance of educational theories for facilitating learning when using technology in medical education. Med Teach. 2015 Nov;37(11):1039-42.

11. Mayer RE. Research-Based Principles for Designing Multimedia Instruction Overview of Multimedia Instruction. Acknowledgement and Dedication. 2014;1-12.

12. Ploetzner R, Lowe R. A systematic characterisation of expository animations. Comput Human Behav. 2012;28(3):781-94. 